\title{
Response of Vegetable Cowpea [Vigna unguiculata (L.) Walp.] to Foliar Application of PGRs
}

\author{
J. P. Sarvaiya ${ }^{1 *}$, S. N. Saravaiya ${ }^{1}$, H. S. Patel ${ }^{1}$ and Y. N. Tandel ${ }^{2}$ \\ ${ }^{1}$ Department of Vegetable Science, ${ }^{2}$ Department of Fruit Science, ASPEE College of \\ Horticulture and Forestry, Navsari Agricultural University, India \\ *Corresponding author
}

\section{A B S T R A C T}

\section{Keywords}

Cow pea, NAA, PCPA, 2,4-D, CCC, Growth and Yield

Article Info

\section{Accepted:}

15 June 2021

Available Online:

10 July 2021
A field experiment was carried out, at the Vegetable Research Farm, RHRS of the NAU, Navsari during Summer 2020 on cv. AVCP 1. The experiment was conducted in randomized block design (RBD) with three replications, which included 13 treatments. The results revealed that application of CCC $300 \mu 11^{-1}$ recorded higher values for growth parameters namely, days to $50 \%$ flowering (57.33 days), leaf area (7058.87 $\left.\mathrm{cm}^{2}\right)$, leaf area index (5.23), days to first picking(67.67 days), number of primary branches plant ${ }^{-1}$ at final picking(8.53), fresh weight of plant at final picking $(0.643 \mathrm{~kg})$, number of cluster plant ${ }^{-1}(35.27)$. Whereas higher values for number of leaves plant ${ }^{-1}$ (57.07) was recorded with the application of NAA $20 \mathrm{mg} \mathrm{l}^{-1}$. Application of CCC $400 \mu \mathrm{l} \mathrm{l}^{-1}$ recorded higher values for plant height at final picking $(57.93 \mathrm{~cm})$ and number of pods $\operatorname{cluster}^{-1}(3.31)$. Foliar application of CCC $300 \mu 1 \mathrm{l}^{-1}$ recorded significantly higher values for pod characters namely, pod length $(14.10 \mathrm{~cm})$, number of marketable pods plant ${ }^{-1}(112.93)$ and marketable pod yield $\left(10.44 \mathrm{t} \mathrm{ha}^{-1}\right)$. From the economic point of view and based on green pod yield, for securing maximum return, foliar application of CCC $300 \mu 1^{-1}$ was found superior with highest $\mathrm{B}: \mathrm{CR}$ value of 2.2 followed by $\mathrm{T}_{11}$ (B:CR value of 2.1 ).

\section{Introduction}

Vegetables are integral part of a balanced diet. Amongst horticultural crops, vegetables have gained importance not only in providing better per unit returns but also in providing nutritional security. The role of vegetables as a major source of phytonutraceuticals like vitamins, minerals, antioxidants and fibers are being well recognized in a balanced diet. Vegetables are important part of healthy dietary and provide source of income to farmers, seed producers, processors and traders (Sable et al., 2020). India is the second largest producer of vegetable in the world after China producing around 188 million 
tonne from just 10.5 million hectare area. Though pulses are grown in both Kharif and Rabi seasons, Rabi pulses contribute more than 60 per cent of the total production. In India total area under cowpea cultivation is 1.5 million hectare whereas, in Gujarat it is cultivated commercially in an area of 0.5 lakh hectare (Anonymous, 2020).

Cowpea (Vigna unguiculata (L.) Walp.), $2 n=2 x=22$ belongs to family Fabaceae, popularly known as chauli is an important legume vegetable crop. It is grown in tropics for its tender green pods and shelled immature seeds used as vegetable and dry seeds used as pulse. It is grown for immature pods and mature grains. The haulms are also fed to livestock. Cowpea is known as drought hardy nature, its wide and droopy leaves keeps soils and soil moisture conserved due to shading effect. It is also known as black-eyed pea or southern pea etc. and has multiple uses like food, feed, forage, fodder, green manuring and vegetable (Saravaiya et al., 2014).

Though, the PGRs have great potential, its application and accurate assessments etc. have to be judiciously planned in terms of optimal concentration, stage of application, species specificity and seasons. In their wide spectrum of effectiveness on every aspect of plant growth, even a modest increase of 10-15 per cent could bring about an increment in the gross annual productivity by $10-15 \mathrm{t} \mathrm{ha}^{-1}$ (Sharma and Lashkari, 2009).

These synthetic PGRs are put into several uses in horticulture, one of them is to increase crop yield and improve quality. The growth behavior of many plants could be modified or controlled by applying small amount of plant growth regulators, either by seed soaking, root dipping or whole plant spray.

Among several growth substances, gibberellins and auxins are very promising and these are being used on large scale in number of vegetable crops. The growth promoters like NAA and 2,4-D enhance the source-sink relationship and modified translocation of photosynthates, which will help in better retention of flowers and fruits and seed filling at the later stages of crop growth. The influence of CCC on the leaf colour can be seen shortly after application. The change in colour is due to a higher chlorophyllsynthesis. To achieve optimum vegetative growth and better translocation of phytosynthates in developing pods, the use of growth regulators appears to be an excellent tool which regulate plant growth and finally alter the plant architecture and yield improvement. However, very rare information is available on this aspect; therefore, the aim of the present study was to investigate the response of foliar application of PGRs on growth, yield and quality of vegetable cowpea.

Hence, the research study entitled "Response of vegetable cowpea [Vigna unguiculata (L.) Walp.] to foliar application of PGRS "using cultivar 'AVCP 1' was carried out at Vegetable Research Farm, Regional Horticultural Research Station, ASPEE College of Horticulture and Forestry, Navsari Agricultural University, Navsari with the following objectives:

To evaluate the effect of foliar application of PGRsviz., NAA, PCPA, 2,4-D and CCC on growth parameters of vegetable cowpea

To evaluate the effect of foliar application of PGRs viz., NAA, PCPA, 2,4-D and CCC on yield parameters of vegetable cowpea

\section{Materials and Methods}

A field experiment entitled "Response of vegetable cowpea [Vigna unguiculata (L.) Walp.] to foliar application of PGRS" was laid out on cowpea during 2020 at Vegetable 
Research Farm, Regional Horticultural Research Station, ASPEE College of Horticulture and Forestry, Navsari Agricultural University, Navsari.

According to agro-climatic conditions of Gujarat state, Navsari falls under 'South Gujarat Heavy Rainfall Zone, AES-III'. The climate of this zone is typically tropical and monsoonic. An average rainfall of the tract is about $1500 \mathrm{~mm}$ and is normally receive by second fortnight of June and cease by September end.

There were thirteen treatment viz. $\mathrm{T}_{1}$ : Control (No spray), $\mathrm{T}_{2}$ : NAA $10 \mathrm{mg} \mathrm{l}^{-1}, \mathrm{~T}_{3}$ : NAA 15 $\mathrm{mg} \mathrm{l}^{-1}, \mathrm{~T}_{4}$ : NAA $20 \mathrm{mg} \mathrm{l}^{-1}, \mathrm{~T}_{5}$ : PCPA $10 \mathrm{mg}$ $\mathrm{l}^{-1}, \mathrm{~T}_{6}$ : PCPA $15 \mathrm{mg} \mathrm{l}^{-1}, \mathrm{~T}_{7}$ : PCPA $20 \mathrm{mg} \mathrm{l}^{-1}$, $\mathrm{T}_{8}: 2,4-\mathrm{D} 0.5 \mathrm{mg} \mathrm{l}^{-1}, \mathrm{~T}_{9}: 2,4-\mathrm{D} 1.0 \mathrm{mg} \mathrm{l}^{-1}, \mathrm{~T}_{10}$ : 2,4-D $1.5 \mathrm{mg} \mathrm{l}^{-1}, \mathrm{~T}_{11}:$ CCC $200 \mu \mathrm{l} \mathrm{l}^{-1}, \mathrm{~T}_{12}$ : CCC $300 \mu 11^{-1}$ and $\mathrm{T}_{13}: \operatorname{CCC} 400 \mu 1 \mathrm{l}^{-1}$.

Observations were recorded for different parameters. The number of days from the date of sowing to date on which 50 per cent of the plants flowers in net plot was recorded as days to 50 per cent flowering for each treatment.

Plant height was measured in centimeter $(\mathrm{cm})$ from ground level to tip of the main stem with the help of measuring tape at final picking. First picking of immature pod for vegetable purpose was started as the pods get marketable size.

The days to first picking were counted from the date of sowing to date of first harvest of individual experimental plot. The days to last picking were counted from date of sowing to date of last picking of each respective plot and it was recorded.

The number of primary branches per plant was counted at the time of final picking and average was worked out. From the five randomly selected pods, the length of pod was measured in centimeter from the stalk to the apex by thread and mean values were worked out. Leaf area was measured with the help of leaf area meter at final picking and average value was worked out. Number of cluster per plant were counted from five tagged plants at the time of each picking and average was worked out.

\section{Results and Discussion}

\section{Influence on growth parameters}

Growth parameters viz., days to $50 \%$ flowering, number of leaves plant ${ }^{-1}$, leaf area, LAI, plant height, days to first picking, days to last, picking number of primary branches plant $^{-1}$, fresh weight of plant, number of cluster plant ${ }^{-1}$ and number of pods cluster ${ }^{-1}$ were significantly influenced by the foliar application of PGRs.

CCC $300 \mu \mathrm{l} \mathrm{l}^{-1}$ found best and recorded the minimum days to $50 \%$ flowering (57.33 days). NAA $20 \mathrm{mg} \mathrm{l}^{-1}$ found best and recorded the maximum number of leaves plant ${ }^{-1}$ (57.07). CCC $300 \mu l l^{-1}$ found best and recorded the maximum leaf area $(7058.87$ $\mathrm{cm}^{2}$ ). CCC $300 \mu \mathrm{l} \mathrm{l}^{-1}$ found best and recorded the maximum leaf area index (5.23).

CCC $400 \mu ~^{-1}$ found best and recorded the minimum plant height at final picking (57.93 $\mathrm{cm})$. CCC $300 \mu \mathrm{ll}^{-1}$ found best and recorded the minimum days to first picking(67.67). PCPA $20 \mathrm{mg} \mathrm{l}^{-1}$ found best and recorded the maximum days to last picking(136). CCC 300 $\mu \mathrm{l} \mathrm{l}^{-1}$ found best and recorded the maximum number of primary branches plant ${ }^{-1}$ at final picking(8.53). CCC $300 \mu \mathrm{l} \mathrm{l}^{-1}$ found best and recorded the maximum fresh weight of plant at final picking $(0.643 \mathrm{~kg})$. CCC $300 \mu \mathrm{l}^{-}$ ${ }^{1}$ found best and recorded the maximum number of cluster plant ${ }^{-1}(35.27)$. CCC $400 \mu \mathrm{l}$ $1^{-1}$ found best and recorded the maximum number of pods cluster ${ }^{-1}(3.31)$. 
Table.1 Effect of foliar application of PGRs on different traits of cow pea cv. AVCP 1.

\begin{tabular}{|c|c|c|c|c|c|c|c|c|}
\hline Treatments & $\begin{array}{c}\text { Days to } 50 \\
\% \\
\text { flowering }\end{array}$ & $\begin{array}{l}\text { Number of } \\
\text { leaves } \\
\text { plant }^{-1}\end{array}$ & $\begin{array}{l}\text { Leaf } \\
\text { area } \\
\left(\mathrm{cm}^{2}\right)\end{array}$ & $\begin{array}{l}\text { Leaf } \\
\text { area } \\
\text { index }\end{array}$ & $\begin{array}{l}\text { Plant } \\
\text { height } \\
\text { (cm) }\end{array}$ & $\begin{array}{c}\text { Days to } \\
\text { first } \\
\text { picking }\end{array}$ & $\begin{array}{l}\text { Days to } \\
\text { last } \\
\text { picking }\end{array}$ & $\begin{array}{c}\text { Number of } \\
\text { primary } \\
\text { branches plant }^{-1}\end{array}$ \\
\hline $\mathrm{T}_{1}:$ Control & 63.00 & 47.80 & 5333.32 & 3.95 & 62.10 & 74.67 & 126.33 & 6.73 \\
\hline$T_{2}:$ NAA $10 \mathrm{mg} \mathrm{l}^{-1}$ & 61.00 & 48.00 & 5801.21 & 4.30 & 69.27 & 72.00 & 119.67 & 7.60 \\
\hline$T_{3}:$ NAA $15 \mathrm{mg} \mathrm{l}^{-1}$ & 60.33 & 56.33 & 6951.77 & 5.15 & 69.60 & 71.33 & 116.00 & 7.93 \\
\hline $\mathrm{T}_{4}:$ NAA $20 \mathrm{mg} \mathrm{l}^{-1}$ & 60.00 & 57.07 & 6879.44 & 5.10 & 70.80 & 71.00 & 117.00 & 8.00 \\
\hline$T_{5}:$ PCPA $10 \mathrm{mg} \mathrm{l}^{-1}$ & 66.00 & 41.53 & 4735.00 & 3.51 & 62.20 & 77.67 & 128.67 & 7.07 \\
\hline$T_{6}:$ PCPA $15 \mathrm{mg} \mathrm{l}^{-1}$ & 66.00 & 43.00 & 4806.98 & 3.56 & 60.83 & 78.33 & 130.33 & 7.00 \\
\hline $\mathrm{T}_{7}:$ PCPA $20 \mathrm{mg} \mathrm{l}^{-1}$ & 67.67 & 44.87 & 5180.40 & 3.84 & 59.87 & 79.00 & 136.00 & 6.67 \\
\hline $\mathrm{T}_{8}: 2,4-\mathrm{D} 0.5 \mathrm{mg} \mathrm{l}^{-1}$ & 61.33 & 45.13 & 5047.09 & 3.74 & 58.70 & 71.33 & 124.00 & 7.13 \\
\hline $\mathrm{T}_{9}: 2,4-\mathrm{D} 1.0 \mathrm{mg} \mathrm{I}^{-1}$ & 62.00 & 46.87 & 5417.95 & 4.01 & 62.77 & 71.33 & 122.33 & 7.53 \\
\hline$T_{10}: 2,4-D 1.5 \mathrm{mg} \mathrm{l}^{-1}$ & 61.67 & 52.67 & 6277.59 & 4.65 & 66.03 & 72.33 & 120.67 & 7.20 \\
\hline T11 : CCC $200 \mu l^{-1}$ & 58.67 & 56.93 & 6957.67 & 5.15 & 61.33 & 69.67 & 117.67 & 7.67 \\
\hline T12 : CCC $300 \mu \mathrm{l}^{-1}$ & 57.33 & 56.27 & 7058.87 & 5.23 & 59.70 & 67.67 & 115.33 & 8.53 \\
\hline T13 : CCC $400 \mu \mathrm{I}^{-1}$ & 58.00 & 52.47 & 6457.25 & 4.78 & 57.93 & 68.33 & 116.67 & 8.07 \\
\hline S.Em. \pm & 2.15 & 3.79 & 464.94 & 0.34 & 2.74 & 2.49 & 4.32 & 0.28 \\
\hline C.D. at $5 \%$ & 6.26 & 11.05 & 1356.85 & 1.01 & 7.99 & 7.26 & 12.60 & 0.81 \\
\hline
\end{tabular}


Table.2 Effect of foliar application of PGRs on different traits of cow pea cv. AVCP 1.

\begin{tabular}{|c|c|c|c|c|c|c|}
\hline Treatments & $\begin{array}{c}\text { Fresh } \\
\text { weight of } \\
\text { plant }(\mathbf{k g})\end{array}$ & $\begin{array}{c}\text { Number of } \\
\text { cluster plant } \\
{ }_{1}\end{array}$ & $\begin{array}{l}\text { Number of } \\
\text { pods cluster }^{-1}\end{array}$ & $\begin{array}{l}\text { Pod length } \\
\text { (cm) }\end{array}$ & $\begin{array}{l}\text { Number of } \\
\text { marketable } \\
\text { pods plant }\end{array}$ & $\begin{array}{c}\text { Marketable pod } \\
\text { yield } \\
\left(\mathrm{t} \mathrm{ha}^{-1}\right)\end{array}$ \\
\hline $\mathrm{T}_{1}:$ Control & 0.434 & 30.27 & 2.89 & 12.34 & 86.98 & 6.04 \\
\hline$T_{2}:$ NAA $10 \mathrm{mg} \mathrm{l}^{-1}$ & 0.591 & 32.00 & 2.92 & 13.53 & 93.30 & 9.06 \\
\hline$T_{3}:$ NAA $15 \mathrm{mg} \mathrm{l}^{-1}$ & 0.599 & 33.07 & 3.09 & 13.66 & 101.45 & 9.56 \\
\hline $\mathrm{T}_{4}:$ NAA $20 \mathrm{mg} \mathrm{l}^{-1}$ & 0.606 & 33.47 & 3.18 & 13.56 & 106.07 & 9.65 \\
\hline$T_{5}:$ PCPA $10 \mathrm{mg} \mathrm{l}^{-1}$ & 0.374 & 31.13 & 2.28 & 12.94 & 70.68 & 4.93 \\
\hline $\mathrm{T}_{6}:$ PCPA $15 \mathrm{mg} \mathrm{l}^{-1}$ & 0.423 & 30.40 & 2.32 & 12.40 & 70.30 & 4.71 \\
\hline $\mathrm{T}_{7}:$ PCPA $20 \mathrm{mg} \mathrm{l}^{-1}$ & 0.421 & 28.67 & 2.41 & 13.11 & 68.84 & 4.57 \\
\hline$T_{8}: 2,4-D ~ 0.5 \mathrm{mg} \mathrm{l}^{-1}$ & 0.438 & 29.53 & 3.04 & 12.79 & 88.87 & 7.17 \\
\hline $\mathrm{T}_{9}: 2,4-\mathrm{D} 1.0 \mathrm{mg} \mathrm{l}^{-1}$ & 0.436 & 31.53 & 2.95 & 12.71 & 92.93 & 7.35 \\
\hline $\mathrm{T}_{10}: 2,4-\mathrm{D} 1.5 \mathrm{mg} \mathrm{l}^{-1}$ & 0.506 & 29.27 & 3.30 & 12.91 & 96.33 & 8.37 \\
\hline$T_{11}:$ CCC $200 \mu \mathrm{I}^{-1}$ & 0.590 & 33.73 & 3.07 & 14.07 & 103.58 & 10.08 \\
\hline$T_{12}: \operatorname{CCC~} 300 \mu \mathrm{I}^{-1}$ & 0.643 & 35.27 & 3.20 & 14.10 & 112.93 & 10.44 \\
\hline$T_{13}:$ CCC $400 \mu \mathrm{I}^{-1}$ & 0.600 & 33.53 & 3.31 & 13.75 & 110.98 & 9.79 \\
\hline S.Em. \pm & 0.06 & 1.34 & 0.16 & 0.37 & 3.73 & 0.55 \\
\hline C.D. at $5 \%$ & 0.16 & 3.92 & 0.48 & 1.08 & 10.89 & 1.61 \\
\hline
\end{tabular}


Table.3 Economics of different treatments (₹ ha $\left.{ }^{-1}\right)$

\begin{tabular}{|c|c|c|c|c|c|c|c|}
\hline Treatments & $\begin{array}{l}\text { Pod yield } \\
\left(\mathrm{t} \mathrm{ha}^{-1}\right)\end{array}$ & $\begin{array}{l}\text { Treatment } \\
\text { Cost }\end{array}$ & $\begin{array}{c}\text { Operational } \\
\text { Cost }\end{array}$ & $\begin{array}{l}\text { Total } \\
\text { Cost }\end{array}$ & $\begin{array}{l}\text { Gross } \\
\text { Return }\end{array}$ & $\begin{array}{c}\text { Net } \\
\text { Return }\end{array}$ & B:CR \\
\hline $\mathbf{T}_{1}$ : Control & 6.04 & 0 & 76765 & 88090 & 181200 & 93110 & 1.1 \\
\hline$T_{2}:$ NAA $10 \mathrm{mg} \mathrm{l}^{-1}$ & 9.06 & 396 & 76765 & 94148 & 271800 & 177652 & 1.9 \\
\hline$T_{3}:$ NAA $15 \mathrm{mg} \mathrm{l}^{-1}$ & 9.56 & 440 & 76765 & 95130 & 286800 & 191670 & 2.0 \\
\hline $\mathrm{T}_{4}:$ NAA $20 \mathrm{mg} \mathrm{l}^{-1}$ & 9.65 & 484 & 76765 & 95343 & 289500 & 194157 & 2.0 \\
\hline $\mathrm{T}_{5}:$ PCPA $10 \mathrm{mg} \mathrm{l}^{-1}$ & 4.93 & 344 & 76765 & 86353 & 147900 & 61547 & 0.7 \\
\hline$T_{6}:$ PCPA $15 \mathrm{mg} \mathrm{l}^{-1}$ & 4.71 & 362 & 76765 & 85958 & 141300 & 55342 & 0.6 \\
\hline $\mathrm{T}_{7}$ : PCPA $20 \mathrm{mg} \mathrm{l}^{-1}$ & 4.57 & 380 & 76765 & 85714 & 137100 & 51386 & 0.6 \\
\hline $\mathrm{T}_{8}: 2,4-\mathrm{D} 0.5 \mathrm{mg} \mathrm{l}^{-1}$ & 7.17 & 310 & 76765 & 90518 & 215100 & 124582 & 1.4 \\
\hline $\mathrm{T}_{9}: 2,4-\mathrm{D} 1.0 \mathrm{mg} \mathrm{l}^{-1}$ & 7.35 & 311 & 76765 & 90857 & 220500 & 129643 & 1.4 \\
\hline $\mathrm{T}_{10}: 2,4-\mathrm{D} 1.5 \mathrm{mg} \mathrm{l}^{-1}$ & 8.37 & 312 & 76765 & 92770 & 251100 & 158330 & 1.7 \\
\hline $\mathrm{T}_{11}: \operatorname{CCC~} 200 \mu \mathrm{I}^{-1}$ & 10.08 & 375 & 76765 & 96040 & 302400 & 206360 & 2.1 \\
\hline $\mathrm{T}_{12}: \operatorname{CCC~} 300 \mu \mathrm{I}^{-1}$ & 10.44 & 419 & 76765 & 96759 & 313200 & 216441 & 2.2 \\
\hline$T_{13}: \operatorname{CCC} 400 \mu \mathrm{l}^{-1}$ & 9.79 & 442 & 76765 & 95563 & 293700 & 198137 & 2.1 \\
\hline
\end{tabular}


NAA and CCC enhanced the early flowering and pod setting. Cycocel application might help the plants to make resistance to drought and could, which is main cause of flower drop and poor pod setting.

These also caused delay in senescence hence increased net period for pod development. Similar results were also found by Kumar et al., (2003) in chickpea; Desai and Deore (1985) in cowpea and Patil et al., (2005) in green gram.

With increasing concentrations of cycocel, there was increase in number of leaves and number of branches. These might be due to the beneficial effect of cycocel. CCC application increased the synthesis of certain endogenous growth substances, which triggers metabolic processes and narrows down the carbon-nitrogen ratio in the plant, stimulating flowering and fruit set. Similar results were also found by Resmi and Gopalakrishnan (2004) in yard long bean as well as Sharma and Lashkari (2009) in cluster bean. PCPA at all levels delayed flowering and fruit harvest. Similar results were also found by Resmi and Gopalakrishnan (2004) in yard long bean.

\section{Influence on pod characters}

CCC $300 \mu \mathrm{l} \mathrm{l}^{-1}$ recorded the maximum pod length among all the treatments. This might be due to faster cell division and enlargement and increase of photosynthetic pigments thereby increase assmilation of all substances and bioconstituents and there translocation from leaf and different plant organs (source) to pod (sink) which ultimately increased the pod length. Similar results were also found by Kumar et al., (2003) in chick pea; Resmi and Gopalakrishnan (2004) in long yard bean; Sharma and Lashkari (2009) in cluster bean.

Number of pods plant ${ }^{-1}$ was maximum in treatment $\mathrm{T}_{12}\left(\mathrm{CCC} 300 \mu \mathrm{l}^{-1}\right)$. This might be due to reduced flower and immature pod drop. The growth regulators prevented formation of abscission layer which resulted the formation of more pods and their retention on plant.

Similar results were also found by Desai and Deore (1985) in cowpea; Patil et al., (2005) in green gram. Das and Prasad (2003) in mung bean also observed a significant increase in number of pods plant ${ }^{-1}$ was due to increased number of branches and fruiting points, which lead to better utilization of sunlight.

CCC $300 \mu \mathrm{l} \mathrm{l}^{-1}$ recorded the maximum pod yield among all the treatments. Increased yields in these treatments can be explained based on the enhanced vegetative growth, increased fruit sizes and higher fruit numbers. Exogenous application of plant growth regulators might be causes a greater accumulation of carbohydrates owing to photosynthesis which accelerate the overall growth of plant result in more number of pods and increase size of seeds ultimately more yield with good quality.

In particular, all concentrations of NAA and CCC showed increased fruit numbers and per plant yield, which may be because of a reduction in flower drop and fruit abortion thereby bring about an improvement in yield potential. Similar results were also found by Resmi and Gopalakrishnan (2004) in yard long bean; Sharma and Lashkari (2009) in cluster bean; Kumar et al., (2003) in chickpea; Das and Prasad (2003) in mung bean; Desai and Deore (1985) in cowpea and Patil et al., (2005) in green gram.

\section{Influence on Economics}

CCC $300 \mu \mathrm{l}^{-1}$ registered the highest net profit $2,16,441 ₹$ ha $^{-1}$ with B:CR value of 2.2 as compared to rest of the treatment, followed by $\mathrm{T}_{11}$ (B:CR of 2.1). Whereas, treatment $\mathrm{T}_{6}$ (PCPA $15 \mathrm{mg} \mathrm{l}^{-1}$ ) and $\mathrm{T}_{7}$ (PCPA $20 \mathrm{mg} \mathrm{l}^{-1}$ ) 
recorded the lowest net realization 55,341.85 and 51,386.35 ₹ $\mathrm{ha}^{-1}$ respectively, with lowest $\mathrm{B}: \mathrm{CR}$ value of 0.6 .

\section{References}

Anonymous (2020). India produces 22 million tonne of pulses in 2018-19. Agric.Today,March,18p.

Das, A. and Prasad, R. (2003). Effect of plant growth regulators $\mathrm{CCC}$ and NAA on the growth and yield of summer mungbean. Ann.of Agric. Res., 24 (4):874-879.

Desai, S. N. and Deore, D. D. (1985). Influence of growth regulators on the seed production of cowpea. $J$. Maharahstra Agric. Uni., 10 (1):89-90.

Kumar, N., Khangarot, S. S. and Meena, R. P.(2003). Effect of sulphur and plant growth regulators on yield and quality parameters of chick pea (Cicer arietinum L.). Ann.Agric. Res. New Series. 24 (2): 434-436.

Patil, S. N., Patil, R. B. and Suryawanshi, Y. B. (2005). Effect of foliar application of plant growth regulators and nutrients on seed yield and quality attributes of mungbean (Vigna radiata (L.) Wilczek.). Seed Res., 33 (2): 142145.

Resmi, R. and Gopalakrishnan, T. R. (2004). Effect of plant growth regulators on the performance of yard long bean (Vigna unguiculata var.sesquipedalis(L.) Verdcourt). Kerala J. Trop.Agric., 42 (1-2): 55-57.

Sable, P. A.; Saravaiya, S. N. and Sharma Ankur(2020). "Vegetable Crops:Package of Practices", Narendra Publishing House, Delhi, India, $623 \mathrm{p}$.

Saravaiya, S. N.; Pandya, H. V.; Chaudhari, K. N.; Patel, G. D. and Kumar, S. (2014). Unaluanechomasurutuno katholvargnoagatyanopak, Choli; Krishigovidhya,67 (1): 8-14.

Sharma, S. J. and Lashkari, C. O. (2009). Response of Gibberellic acid and Cycocel on growth and yield of Cluster bean (Cyamopsistetragonoloba L.) cv. 'Pusa Navbahar'. Asian J. Hort., 4 (1): 89-90.

\section{How to cite this article:}

Sarvaiya, J. P., S. N. Saravaiya, H. S. Patel and Tandel, Y. N. 2021. Response of Vegetable Cowpea [Vigna unguiculata (L.) Walp.] to Foliar Application of PGRs. Int.J.Curr.Microbiol.App.Sci. 10(07): 293-300. doi: https://doi.org/10.20546/ijcmas.2021.1007.031 